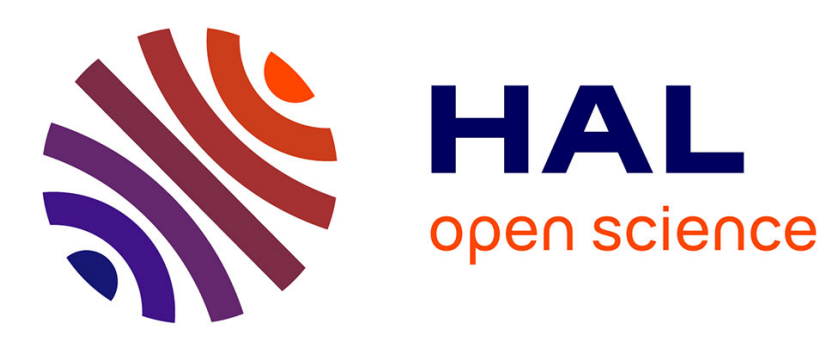

\title{
Using Mobile Devices and Online Tools to Promote Students' Learning
}

Ana Amelia Carvalho

\section{To cite this version:}

Ana Amelia Carvalho. Using Mobile Devices and Online Tools to Promote Students' Learning. 1st International Conference on Sustainable ICT, Education, and Learning (SUZA), Apr 2019, Zanzibar, Tanzania. pp.7-15, 10.1007/978-3-030-28764-1_2 . hal-02515739

\section{HAL Id: hal-02515739 \\ https://hal.inria.fr/hal-02515739}

Submitted on 23 Mar 2020

HAL is a multi-disciplinary open access archive for the deposit and dissemination of scientific research documents, whether they are published or not. The documents may come from teaching and research institutions in France or abroad, or from public or private research centers.
L'archive ouverte pluridisciplinaire HAL, est destinée au dépôt et à la diffusion de documents scientifiques de niveau recherche, publiés ou non, émanant des établissements d'enseignement et de recherche français ou étrangers, des laboratoires publics ou privés. 


\title{
Using Mobile Devices and Online Tools to Promote Students' Learning
}

\author{
Ana Amelia Carvalho ${ }^{[0000-0002-0621-9447]}$ \\ University of Coimbra, Coimbra 3000-115, Portugal \\ anaameliac@fpce.uc.pt
}

\begin{abstract}
Keeping students' attention in class and engaging them in learning is not an easy task. In this paper we report the approaches and strategies used in a university course 'Games and Learning'. An action research study was conducted involving three cycles. During the first one, a flipped learning approach was used to motivate students to read the papers before class. In the classroom, students had to use their mobile devices to answer quizzes, fill a form, and summarize the lesson. During the following cycles, students worked in groups, analyzing digital games. Along the second cycle students analyzed a video game and during the third cycle they analyzed a serious game. We realized that asking them to submit some tasks online before class, helped them to work more and achieve better results. From the first group work to the second one the majority of students improved their critical digital game analysis. The collected data supported the conclusion that students were engaged in learning.
\end{abstract}

Keywords: Mobile Devices, Flipped Learning, Students’ Engagement.

\section{Introduction}

\subsection{Challenges to Higher Education}

Nowadays, one of the greatest challenges colleges and universities are facing is how to get students engaged in learning and how to provide an education of real value to their students. Some complaints about students are very common: students lack the required skills, they are short on motivation, and they have insufficient focus and attention.

Some faculty members try to motivate and engage students in learning, pushing them to active roles. However, some students often resist. Students' resistance to learning is a systemic problem, as Tolman and Kremling [1] analyzed in their book. Indeed, although the great majority of students prefer taking active roles [2-7], a few students resist to it [8]. 


\subsection{Some Students' Characteristics}

Some characteristics of our students, as reported by several authors [9, 4, 10-11] are important to be considered when planning classes.

i) Students are used to being online, connected to friends using Facebook, Instagram, WhatsApp, etc. They are used to get feedback almost instantly. They are used to immediacy.

ii) They bring and use their mobile devices all the time, facilitating the implementation of the idea of Bring Your Own Device (BYOD). Indeed, it is wise to use their mobile devices to get students engaged in learning.

iii) Quite often they have a low capacity of attention. A traditional lecture class is difficult for them to follow. The alternative is to reduce the teacher's presentation time, replacing it with an active learning approach.

\subsection{The Course 'Games and Learning'}

In this paper, we describe and reflect on our experience in motivating and engaging higher students in learning. When planning classes and thinking about which approach to use, we considered the previous characteristics of students presented in section 1.2.

The course 'Games and Learning' is for undergraduate students from the $2^{\text {nd }}$ and $3^{\text {rd }}$ year, of Education Sciences Program in the Faculty of Psychology and Education Sciences, at the University of Coimbra, in Portugal. One of our concerns is to keep students' attention and interest during the class but also to motivate them to be critical to digital games analysis.

The course is divided into three parts, all of them related to each other. The first part of the course focuses on theoretical background about games and particularly about digital games. Games definition, the games genres, and the pros and cons of playing digital games are discussed. The learning principles under digital games according to James Paul Gee [12] are presented. Finally, the last topic is about serious games.

The second part is about the critical analysis of a digital game, a mainstream game. It is a group work with no more than three elements. Students have to write a report about their game analysis and to give a presentation in class.

The third and last part of the course is about the critical analysis of a serious game. This second group work is more demanding. It also includes a study with game players, checking their satisfaction with the game.

The next section presents the teaching approaches used, supported by the use of apps and students' mobile devices.

\section{Teaching Approaches and Online Tools Used}

Throughout the last few years, we recognized that students have ever more difficulty in keeping attention during lectures. So we have embraced active learning approaches. Moreover, we are using their mobile devices to connect them to the web for 
searching, answering to quizzes or fill in questionnaires. We intend to motivate students to be critical about digital games: what is good and what is not, and how can they be improved.

\subsection{Active Learning}

Active learning is "anything that involves students in doing things and thinking about the things they are doing” [13] (p. 2). As Felder and Brent [6] pointed out, students should be "called upon to do other things than simply watching, listening and taking notes” (p. 2). But “you are not doing active learning when you lecture, ask questions that the same few students always answer, or conduct discussions that engage only a small fraction of the class" (ibidem). They must read, write, discuss, or be engaged in solving tasks. Students must engage in higher-order thinking tasks such as analysis, synthesis, and evaluation. The activity usually takes from 15 seconds to 3 minutes [6], for example, to share a point of view or discuss a result. If more time is needed, Felder and Brent advise to break the problem into several steps and treat each step as a separate activity. Students "work individually or in small groups to come up with a response; give them some time to do it; stop them, and call on one or more individuals or groups to share their responses” (p. 2) [6]. There are several activities to be considered, for example, Quizzes online, Brainstorming, forms, Think-Pair-Share, Peer Instruction, One-Minute-Paper, MindMapping, Full Body Response (FBR), Exit ticket, and so on. Active learning engages students in the learning process [7].

\section{Flipped Learning}

The main idea of flipped learning, initially called flipped classroom [14], is to increase interaction and personalized contact time between students and teachers [15]. Students do activities traditionally considered "homework" in class and activities traditionally considered as in-class work out of class. Before class, students watch videos and/or read previously given references. They have to get familiar with concepts. During class they work in small groups applying knowledge, analyzing things, evaluating or creating things. They can solve problems or projects in the class and after.

\subsection{Bring Your Own Mobile Devices}

Students bring their own mobile devices, which may facilitate activities in the classroom. They can be invited to search for information, answer multiple choice questions or concept tests. They can be challenged to do short activities as proposed in the active learning approach.

Usually, two rules are important to be respected in the classroom: students must turn off the sound of their mobile devices and they used the devices only when asked by the teacher.

Using students` mobile devices in the classroom, to answer a quiz online, for example, allows all students to see their own and the class results. Based on their 
answers, the teacher may move further or explain again a concept that was not very clear to students [4].

\subsection{Online Tools}

We used several online tools during the semester for different purposes as we will explain.

\section{Online Quizzes}

The app Kahoot is motivating for students. It has music, the question is projected and each student can see, per question, his/her result and then the five best respondents. However, it has a problem. As students are seated side by side and answering the same question, they can check the answers with their colleagues or copy their answers. Usually, they have only a few seconds to answer each question, to avoid the chance to compare answers or to help each other. This problem is solved with the app Quizizz.

With the app Quizizz it is possible to randomize the order of the questions and the order of the list of options. Therefore, each student answers different questions simultaneously. It has also music. The teacher and the students in the classroom can see a results bar along the quiz resolution.

In table 1, we compare some features of Kahoot and Quizizz regarding quizzes. Besides the previously referred features, it is important to note that Kahoot has a limitation in the use of characters allowed per question and per answer.

Table 1. Quizzes comparison between the apps Kahoot and Quizizz

\begin{tabular}{lll}
\hline Features & Kahoot & Quizizz \\
\hline Background Music & Yes & Yes \\
Timer & Yes & Yes \\
Projection of Questions & Yes & No \\
Feedback per Question & Yes & Yes \\
Random Questions & No & Yes \\
Limit of characters & Yes & No \\
Leaderboard & Yes & Yes \\
Homework & Yes & Yes \\
\hline
\end{tabular}

Another app that we use quite often is GoSoapBox. It does not have music, nor timer per question, but it is possible to create open questions. In what concerns feedback for the students, they can only see their results at the end of the quiz.

\section{Google Forms}

Google Forms were used for collecting data from questionnaires, students' opinion about a topic, and to summarize what they had learned at the end of class. 
During group work development, students had to fill in a form related to the task assigned for that week.

\section{$3 \quad$ Methodology}

Based on the difficulties of students to get attention and focus in the class, and to get engaged in learning, we delineated two research questions: (i) How to keep students' attention and interest in class? and (ii) How to promote students' learning?

We used an action research methodology [16-19] to reflect and to improve the educational practices. Each cycle of action-research has three parts: planning, action, and reflection.

The aims of this study are: getting students' attention and interest in the class, promoting students learning, and developing critical digital games analysis.

As data collection techniques we used questionnaires and observation.

\subsection{Data Collection Instruments}

We developed two questionnaires. One to characterize students' game preferences and another to collect students' opinions about the course 'Games and Learning”. The first one was filled in at the beginning of the semester and the second one at the end of the semester. The questions were multiple choice or open-ended questions.

\subsection{Participants Characterization}

The majority of respondents $(n=30)$ were female $(73 \%)$. Their ages ranged from 18 to 35 years. The mode is on their twenties, the majority of respondents is between 18-20 years, one student is 24 and another 35 years.

Half of the students enrolled in this elective course named 'Games and Learning' are from the $2^{\text {nd }}$ year, $39 \%$ from the $3^{\text {rd }}$ year and $11 \%$ are Erasmus Mobility Students.

They selected the course due to their interest in the thematic and the syllabus. Most of the students (83\%) liked to play games and some (17\%) indicated that it depended on the game. The great majority (90\%) also liked to play digital games on their smartphones.

They liked to play the following traditional games: card games (like Sueca and Poker), Monopoly, Pictionary, and Clue. Asked about digital games that they liked to play, they indicated the following: The Sims, Call of Duty, Candy Crush, and Clash Royale.

\section{Data Analysis}

The data analysis is structured into three parts, each one corresponds to a cycle of action research. Each cycle analyses the effect of the approach used in students 
engagement and learning, and, according to its results, we changed some aspects in the following cycle.

Each cycle corresponds to a different part of the course named 'Games and Learning', which has been explained in section 1.3.

\section{1 $\quad 1^{\text {st }}$ Cycle - Theoretical Background}

To motivate students to attend the classes and to do the readings, we used the Flipped Learning approach [15]. Every week, they had to read a paper before class. Students were also requested to bring a mobile device because they would need it during class. Mobile devices were used to do short tasks during the class, according to the active learning approach [6]. By using their mobile devices to fill in some forms, answer online quizzes or to write some information, enabled us to have access to their responses. And this way, we avoided the use of paper, thus contributing to sustainable practices.

At the beginning of each class, students answered a quiz online about the paper read during that week, receiving immediate feedback for each question. Two apps were used: Kahoot and Quizizz. We identified two advantages to this approach: students read the papers and arrived on time to the classroom.

With the quizzes results, the teacher had the opportunity to emphasize the most relevant concepts or ideas of the paper and answered some students' doubts. The teacher asked students about some aspects of the paper, and stimulated them to develop critical thinking.

To help them to keep attentive during the two-hour class, they were invited to summarize what they had learned that day, using a Google Form.

Based on the questionnaire results, students liked the approaches used (97\%). They read the paper at home, answered quizzes, and were able to discuss the main ideas. Only a resistant student indicated that she preferred a traditional approach instead. Either way, all students reported that they felt engaged during classes.

Almost all students considered that summarizing what they learned during each session, motivated them to be focused on the class (97\%). The quizzes solved at the beginning of each class motivated them to study and read the papers each week (97\%). For the following cycle we decided to keep the summarizing activity.

\section{2 $\quad 2^{\text {nd }}$ Cycle - Video game Analysis}

The second part of the course was dedicated to the analysis of a video game. This work was developed in small groups (of 3 elements) and implied a critical analysis of a video game according to specific items, namely: general video game characterization, game description, identification of the learning principles of James Paul Gee [12] in the video game, tangential learning, and a final commentary about the video game. For the latter, they were asked to reflect on the most and least successful aspects related to challenges, engagement, immersion, and flow [20], as well as its adequacy to the target audience. Throughout two classes, students received support from the teacher and colleagues. 
Before the $1^{\text {st }}$ session of group work, students had to fill a form indicating their team members and the chosen video game, which had to be approved by the teacher. The games selected were: Age of Empires II: The Conquerors; Asphalt 8: Airborne; Battle Warship: Naval Empire; Clash of Clans; Clash Royale; Counter Strike 1.6; Counter Strike: Global Offensive; Fortnite; GTA; Matchington Mansion; Pokémon Go; and Two Point Hospital.

During the third week, they presented their analysis and submitted a report. Some students were not very confident during their presentation. It seemed that they left the work to the last minute. The grades were not very high.

According to our experience, having a task to be completed before class as advantages both to the students and to the teacher. Students will have to solve the task before the class and the teacher may give students a written feedback. In the classroom the teacher has more time to clarify some group's doubts. We realized that with no previous task online, some students did not work properly. Based on these observations, a task online has been included previously to each session to the next group work.

\section{3 $\quad 3^{\text {rd }}$ Cycle - Serious Game Analysis}

The third part of the course was dedicated to a critical analysis of a serious game. This group work is more demanding as students had to collect data about gamers' satisfaction.

The serious game analysis focused on a general serious game characterization, game description, and the identification of a learning theory under game development. The following step was to describe player's reactions to the serious game. Particularly, if they had some difficulties in playing it and the degree of satisfaction obtained by playing the game. Finally, a commentary about the serious game analyzed: the best aspects and those not so successful, as well as some solutions to the problems (if identified). Finally, they had to comment about its adequacy to the target audience.

They had four tasks. Three of them had to be filled in a Google Form one day before the class. Task 1 was about the team elements, a definition of serious game and the game selected, which had to be accepted by the teacher. Task 2 was a game description, and they had to identify the best and the worst aspects of the game. With this analysis, they knew quite well the game and were prepared for planning Task 3: analyzing gamers' satisfaction. This task intended to help students to define: What do you intend to observe?, Where are you going to observe?, What kind of data collecting instrument are you going to use?, How can you measure the gamers' satisfaction? Some groups filled it very well but others had difficulties. It seemed that they could not understand what was being asked. Most of the groups submitted their instruments to collect data for teacher's approval.

Task 4 was accomplished after group presentation. They had to fill a Group SelfAssessment questionnaire about the game analysis. If the group considered that the team members worked differently, they could indicate the difference among them. 
Only two groups indicated differences in team members engagement during group work.

Students (97\%) reported, in the Questionnaire of Opinion, that the digital games analyses promoted the development of critical thinking about game features. When asked what they liked most in the classes, they mentioned the digital games analyses, the quizzes, the teaching approaches used, the interactive classes, and the summary to be written online at the end of each class. Relatively to what they disliked during the course, the great majority said that they did not have anything to point. A few reported some noise in the class during group work, and the fact that some colleagues did not work as expected in the group tasks. Asked about suggestions to improve the course, the majority liked it as it was, but some mentioned that they would like to design a game.

When asked about their prevision of the final grade (in a 0 to 20 scale), $40 \%$ indicated the correct grade, $33 \%$ were one value below, $10 \%$ were one value above, and $17 \%$ overestimated their grade.

\section{Conclusion}

In the course 'Games and Learning', attention and interest was achieved by keeping students active in class, namely: answering an online quiz using their mobile device, discussing paper ideas, and writing in a Google form "What did you learn today?". This last idea came up during the first class, when some students were distracted or talking to their colleagues. To keep them quiet and following the activities in the class, this idea emerged. Summarizing the class at the end was the leitmotif to keep them attentive and taking notes.

Students learning was promoted differently in the three parts of the course. The first part of the semester relied on reading a paper before class, based on the flipped learning approach. In class they began by answering an online quiz about the paper using their mobile device. This motivated the students to read the paper, and they were on time in the classroom.

The second and third parts of the semester were devoted to digital game analysis: a mainstream game and a serious game, respectively. It was very important to define tasks to be filled online by each group work. It helped students to be more organized, working and discussing in advance to the class. The teacher gave students an online feedback about the task accomplished, and supported in the classroom the groups with more difficulties.

Students liked the approaches used in the course, and they developed critical digital games analysis. The course tasks and activities are very demanding for the teacher. There are lot of things to plan, to create and feedback to provide to students. However, their engagement, performance and satisfaction compensated the effort and time consuming.

The results achieved are consistent with other studies. For example, Fisher, Perényi and Birdthistle [21] concluded that "flipped learning pedagogy is inherently satisfying to students independent of their perceptions of performance”. Ranieri, Raffaghelli 
and Bruni [22] pointed out that the use of quizzes "showed a high level of student satisfaction and an overall improvement of learning outcomes". However, there are differences in terms of effectiveness according to the nature of topics: more theoretical knowledge or the use of knowledge in a more practical context [22].

The ideas and results presented in the paper are also relevant for developing countries. In this paper we explained how we used students' mobile devices to get them engaged in learning. Moreover, we presented approaches that can be used by other teachers interested in improving their teaching, motivating students to read the material before class, and getting them engaged in the class activities.

Acknowledgements. The research presented in this paper is in part supported by LabTE FPCE-UC and CEIS20 at University of Coimbra.

\section{References}

1. Tolman, A., Kremling, J. (eds): Why Students Resist Learning? Stylus, Sterling (2017).

2. Ahmed, I., Roussev, V.: Peer Instruction Teaching Methodology for Cybersecurity Education. IEEE Security \& Privacy 16(4), 88-91 (2018).

3. Budhai, S., Skipwith, K.: Best practices in Engaging online learners through active and experiential learning strategies. Routledge, London (2016).

4. Carvalho, A., Machado, C.: Flipped Classroom and Quizzes to motivate learning: students' perspectives. In: Information Systems and Technologies, pp. 752-757. AISTI (2017). DOI: $10.23919 /$ CISTI.2017.7975851

5. Eison, J.: Using active learning instructional strategies to create excitement and enhance learning. University of Florida (2010).

6. Felder, R., Brent, R.: Active learning: an introduction. ASQ Higher Education Brief 2(4) (2009).

7. Prince, M.: Does Active Learning Work? A Review of the Research. Journal of Engineering Education 93(3), pp. 223-231(2004).

8. Tolman, A., Sechler, A., Smart, S.: Defining and Understanding student resistance. In: Tolman, A., Kremling, J. (eds.) Why Students Resist Learning? Stylus, Sterling, pp. 1-20 (2017).

9. Carr, N.: The Shallows - What the Internet Is Doing to Our Brains. Norton, New York (2011).

10. Couch, C., Mazur, E.: Peer Instruction: Ten years of experience and results. American Association of Physics Teachers 69(9), 970-977 (2001).

11. Veen, W., Vrakking, B.: Homo Zappiens: Growing up in a digital age. Network Continuum Education (2007).

12. Gee, J.: What Video Games Have to Teach Us About Learning and Literacy. Palgrave MacMillan, New York (2003).

13. Bonwell, C., Eison, J.: Active Learning: creating excitement in the classroom. ASHEERIC Higher Education Reports $N^{0} 1$. The George Washington University, School of Education and Human Development, Washington, D.C. (1991).

14. Bergmann, J., Sams, A.: Flip your classroom: reach every student in every class every day. ISTE, Eugene (2012).

15. Bergmann, J., Sams, A.: Flipped Learning: Gateway to Student Engagement. ISTE, Alexandria (2014). 
16. Cohen, L., Manion, L., Morrisson, K.: Research methods in education. $8^{\text {th }}$ edn. Routledge, London (2018).

17. McNiff, J. Whitehead, J.: You and your action research project. $3^{\text {rd }}$ edn. Routledge, London (2010)

18. Ferrance, E.: Action Research. LAB - Northeast and Islands Regional Educational Laboratory at Brown University, Providence (2000).

19. Akker, J.: Principles and methods of development research. In: Akker, J., Branch, R., Gustafson, K., Nieveen, N., Plomp, T. (eds) Design Approaches and Tools in Education and Training, pp. 1-14. Kluwer Academic Publishers, Dordrecht (1999).

20. Czikszentmihalyi, M.: Flow: the psychology of optimal experience. Harper Perennial, New York (2008).

21. Fisher, R., Perényi, Á., Birdthistle, N.: The positive relationship between flipped and blended learning and student engagement, performance and satisfaction. Active Learning in Higher Education (2018). https://doi.org/10.1177/1469787418801702

22. Ranieri, M., Raffaghelli, J., Bruni, I.: Game-based student response system: Revisiting its potentials and criticalities in large-size classes. Active Learning in Higher Education (2018). https://doi.org/10.1177/1469787418812667 